\title{
Effects of landscape restoration on soil water storage and water use in the Loess Plateau Region, China
}

\author{
Liding Chen ${ }^{\mathrm{a}, *}$, Jiping Wang ${ }^{\mathrm{a}, \mathrm{b}}$, Wei Wei ${ }^{\mathrm{a}}$, Bojie $\mathrm{Fu}^{\mathrm{a}}$, Dongping $\mathrm{Wu}^{\mathrm{c}}$ \\ a State Key Laboratory of Urban and Regional Ecology, Research Center for Eco-Environmental Sciences, Chinese Academy of Sciences, Beijing 100085, China \\ ${ }^{\mathrm{b}}$ Graduate University of Chinese Academy of Sciences, Beijing 100035, China \\ ${ }^{\mathrm{c}}$ Dingxi Institute of Soil and Water Conservation, Dingxi, Gansu Province 743000, China
}

\section{A R T I C L E IN F O}

\section{Article history:}

Received 19 January 2009

Received in revised form 30 September 2009 Accepted 22 October 2009

\section{Keywords:}

Land cover types

Vegetation restoration

Evapotranspiration

Soil water

Water stress

Loess Plateau

China

\begin{abstract}
A B S T R A C T
Large-scale vegetation restoration in China's Loess Plateau has been initiated by the central government for controlling soil and water losses in the past three decades. However, there is virtually no guidance for plant species selection for the restoration purpose. We investigated the effects of planting trees and shrubs, land-use conversions from croplands to pastures and native grasslands on soil water dynamics and water stresses by using long-term field measurements from 1986 to 1999 in the semi-arid loess hilly area. Our research has led to the following three major findings. Firstly, the amount of soil water storage within a $100 \mathrm{~cm}$ depth decreased as measured at both the beginning and the ending point of growing seasons regardless land cover types. The soil water replenishment by rainfall during rainy seasons was not sufficient to fully recharge the soil water storage. Landscape restoration through shrub planting may help retain more soil water than other land cover types. Secondly, the ratio of actual evapotranspiration $(E T)$ and pan evaporation (PET) generally declined for all land cover types during the study period. Shrub lands had the largest ET/PET ratio, followed by native grassland, cropland/alfalfa, and pine woodland. The ET/PET ratio of native grasslands declined fastest, followed by pine woodlands, shrub lands, alfalfa, and croplands. Pine woodland's low ET/PET ratios were mainly caused by its higher runoff due to soil compaction resulted from soil desiccation. Lastly, we found that the soil water storage at the beginning of growing season was important in determining the ET/PET ratios. This study suggested that pine plantations may not be appropriate for landscape restoration in such a semi-arid loess hilly area while shrubs may be highly recommended.
\end{abstract}

(c) 2009 Elsevier B.V. All rights reserved.

\section{Introduction}

In arid and semi-arid regions, vegetation restoration is largely controlled by soil water availability (Porporato et al., 2002; Wang et al., 2002). Plants, through their contrasting capacity to access, transport, and transpire soil moisture, have strong impacts on ecosystem water balances (Nosetto et al., 2007). Theoretically, vegetation restoration can improve vegetation coverage, increase rainfall interception and water retention, thus reduce soil erosion and nutrient loss, enhance terrestrial and aquatic habitat, and increase carbon sequestration (Huang et al., 2003; Sun et al., 2006). However, improper vegetation practices can also induce unwanted environmental problems. For example, in China's semiarid Loess Plateau, tree plantations consumed too much water due to increased evapotranspiration, and thus undermined the natural water cycle and balance (Hou et al., 1999; Wu and Yang, 1998).

\footnotetext{
* Corresponding author. Fax: +861062849102.

E-mail address: liding@rcees.ac.cn (L. Chen).
}

As a severe soil erosion area in the world, the Loess Plateau has received much attention for a long time in China. A great deal of efforts on soil erosion control and vegetation restoration has been made by the central government (Chen et al., 2007, 2008; Fu et al., 2005; Wei et al., 2006; Xu et al., 2009; Zhang et al., 2008). However, poor vegetation coverage still remained a threat to soil erosion in the Loess Plateau region. In the past three decades, a series of large reforestation campaigns, such as the "Grain-forGreen" project, was initiated in 1999. Usually, fast-growing tree and shrub species were used for vegetation restoration. These trees and shrubs often grow well at the beginning, but not at the late stages when soil water is depleted (Li, 2001; Yuan and $\mathrm{Xu}, 2004$ ). Huang et al. (2001) found that planting apple trees tended to increase evapotranspiration and decrease soil water compared with planting winter wheat (Liu and Huang, 2002). Other studies also suggest that planting tree can decrease soil moisture content in the upper surface soil layer while the deep soil water cannot be recharged by natural rainfall (Yang and Rong, 2007; Mu et al., 2003). Water over-use by plants has resulted in a soil desiccation phenomena (Shangguan and Zheng, 2006; Chen et al., 2008) that 
may further hamper plant growth and natural vegetation succession. Since the early 1990s, much attention has been paid to the soil desiccation due to artificial reforestation (Yang and Tian, 2004; Ran et al., 2008). Soil desiccation was often observed after a long arborvitae plantation because of strong evapotranspiration (Huang and Gallichand, 2006; Li and Shao, 2006; Wang, 2007). However, it may also appear seasonally in natural grasslands such as Bothriochloa ischaemum and Stipa bungeana (Wang et al., 2002).

Soil desiccation may affect plant evaporation and growth (Huang et al., 2003). It can undermine the anti-drought capability of deep-rooted plants, and thus affect vegetation growth and natural succession. It may also alter the linkage between rainfall and ground water, and result in micro-climate drying and land productivity declining (Mu et al., 2003; Li, 2001; Wang et al., 2007). Past studies showed that plant evapotranspiration in the loess hilly areas declined when soil water was limited and soil desiccation developed (Yang et al., 2004). This further caused artificial forest and grassland degradation, resulting in "smallaged-tree", a tree with very low trunk after grown up, in the semiarid loess hilly area (Hou et al., 1999; Yang and Tian, 2004). Research conducted in the Zifanggou catchment in the northern Loess Plateau by Wang et al. (2002) indicated that the native species had higher ET/PET ratio and better soil moisture than exotic species, and vegetation restoration may result in soil desiccation if exotic species were introduced.

The overall goal of this study was to quantify ecosystem water balances among typical land covers in landscape restoration practices on the hilly Loess Plateau region in China. The specific objectives were to 1) examine how soil moisture storage changes over time among different land covers, 2) quantify changes of actual evapotranspiration/potential evapotranspiration (ET/PET) ratio and evapotranspiration/precipitation $(E T / P)$ ratio over time among difference land covers.

\section{Methods}

\subsection{Study area}

This study was conducted at Dingxi Soil and Water Conservation Experimental Station in Anjiapo catchment, Gansu Province of China (Fig. 1). It is located in the western part of the Loess Plateau that has a semi-arid temperate climate. Annual mean rainfall is about $408 \mathrm{~mm}$ (1958-2004) with over $80 \%$ falling in the period of May to September. Annual potential evapotranspiration as measured by pan evaporation method is approximately $1500 \mathrm{~mm}$. Mean daily maximum temperature in July is $31.2^{\circ} \mathrm{C}$, and mean minimum temperature in January is $-14.2{ }^{\circ} \mathrm{C}$.

Soil in the study area is the Calcic Cambisol group based on FAOUNESCO soil classification system. It is composed of 39\% clay $(<0.01 \mathrm{~mm}), 50 \%$ silt $(0.01-0.05 \mathrm{~mm})$ and $11 \%$ sand $(>0.05 \mathrm{~mm})$. The soil field capacity is about $18-24 \%$, and soil organic matter is around $0.4-1.3 \%$. Soil bulk density ranges from 1.09 to $1.36 \mathrm{~g} \mathrm{~cm}^{-3}$. Soil thickness varies from 40 to $60 \mathrm{~m}$ in the region.

Vegetation restoration has been widely implemented since the late 1970s in the area where Chinese pine (Pinus tabulaeformis), oriental arborvitae (Platycladus orientalis), little leaf peashrub (Caragana microphylla) and sea buckthorn (Hipporhae rhamnoides L.) were planted. Current land cover types include arable land, abandoned cropland, alfalfa grassland, native grassland, shrub lands and tree plantations. Major crops are spring wheat (Triticum aestivum L.), soybeans (Vigna angularis), potatoes (Solanum tuberosum L.), millet (Panicum miliaceum), sorghum (Sorghum spp.), and major grasses include Stipa breviflora, Stipa bungeana and Thymis mongolicus.

\subsection{Experimental design and field installations}

Fifteen experimental plots were constructed on the hillslopes between $10^{\circ}$ and $20^{\circ}$ slopes where rainfed crops (i.e., winter wheat and potatoes) were grown previously. Plots used for shrub lands and pine plantations were $10 \mathrm{~m} \times 10 \mathrm{~m}$, while plots used for slope cropland, alfalfa grassland and native grassland were $10 \mathrm{~m} \times 5 \mathrm{~m}$. Pine and Sea Buckthorn were planted in 1978, and alfalfa was planted when the plots were built in 1986. Each plot was constructed with a cement ridge of $30 \mathrm{~cm}$ above ground around the borders, and an H-flume was used to measure surface runoff. For each land cover type, three replications were used. Detailed information about the experimental design was described in Table 1. We assumes that environmental factors such as soil properties (i.e., texture), topography, and micrometeorology were similar among all plots, and did not contributed to the observed differences in $E T$, runoff, and soil moisture content.

Soil moisture of $0-100 \mathrm{~cm}$ profiles were measured for every $20 \mathrm{~cm}$ depth during May to September of the growing season in 1986-1999. The measurements were usually made at the 1 st and the 16th of each month. Gravimetric soil moisture content was measured by taking soil samples using the auger. At each plot, four spots were randomly chosen to take samples for estimate the averages. Soil samples were taken on site for the $10 \mathrm{~m} \times 10 \mathrm{~m}$ plots, and soil was backfilled and the surface was flatted each time.

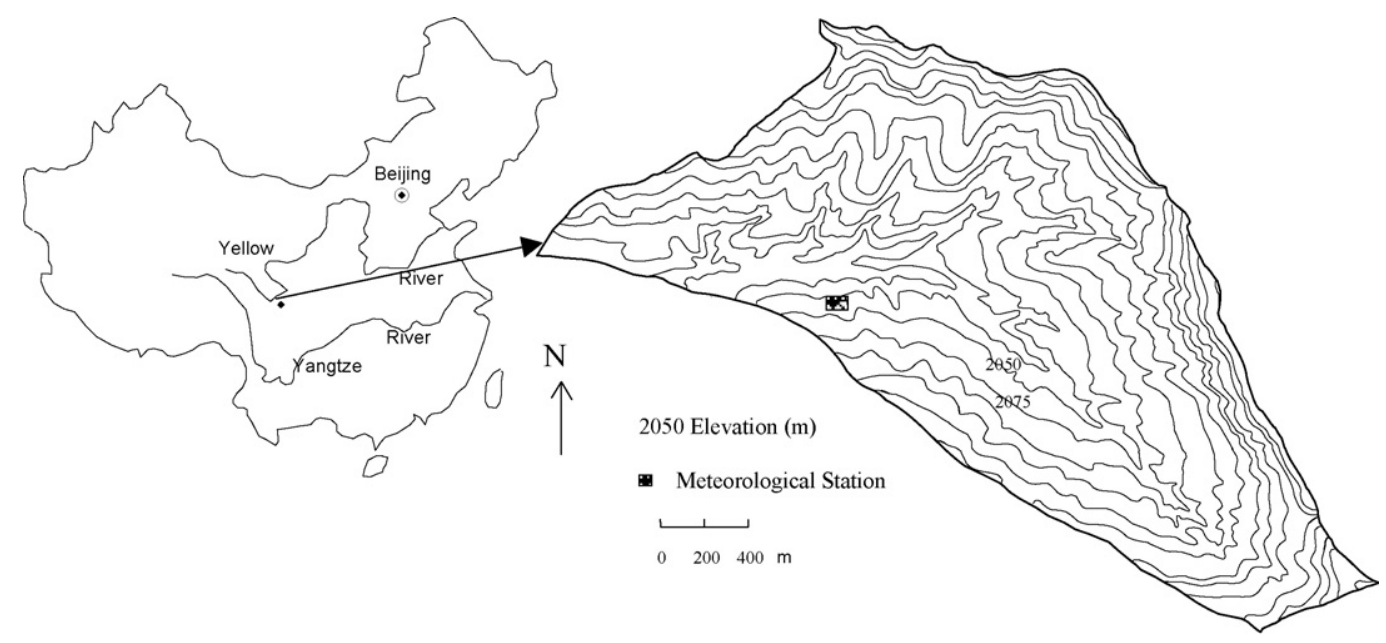

Fig. 1. Location of the study area. 
Table 1

General information of the plots.

\begin{tabular}{|c|c|c|c|c|c|c|c|}
\hline Vegetation type & Species & $\begin{array}{l}\text { Slope } \\
\left({ }^{\circ}\right)\end{array}$ & Soil type & $\begin{array}{l}\text { Coverage in the first } \\
\text { three years (\%) }\end{array}$ & $\begin{array}{l}\text { Coverage after } \\
\text { three years (\%) }\end{array}$ & Understory & Replication \\
\hline Cropland & Spring wheat (T. aestivum) & $10-20$ & & $0-50$ & $0-50$ & NA & 3 \\
\hline Alfalfa grassland & Purple alfalfa (M. sativa) & $10-20$ & & $70-95$ & $35-50^{*}$ & NA & 3 \\
\hline Native grassland & $\begin{array}{l}\text { Native grassland } \\
\text { (Stipa breviflora, S. bungeana, and Thymis mongolicus) }\end{array}$ & $10-20$ & $\begin{array}{l}\text { Calcic } \\
\text { cambisol }\end{array}$ & $80-95$ & $75-85$ & NA & 3 \\
\hline Shrubland & Sea buckthorn (Hippophea rhamnoides) & $10-20$ & & $40-95$ & $90-100$ & High & 3 \\
\hline Pine woodland & Chine Pine (Pinus tablaeformis) & $10-20$ & & $15-37$ & $60-80$ & Low & 3 \\
\hline
\end{tabular}

" Note: The alfalfa at the plots was repaired each year after the 8th year due to its severe degradation.

However, soil samples were collected beside the plots for the $10 \mathrm{~m} \times 5 \mathrm{~m}$ plots for reducing the disturbance.

Surface runoff of each land cover plot was collected from May to September in the period of 1986-1999. Each time, the collectors were cleaned up after the measurement, and the surface runoff modulus was calculated. The rainfall, temperature, and other meteorological parameters were recorded automatically from 1986 to 1999 at a meteorological station nearby the runoff plots. Manual measurements were also made on rainfall used for checking automatically recorded data. The pan evaporation was measured at the weather station as well.

\subsection{Water balances}

Change in soil water in the growing seasons $(\Delta S)$ was calculated as:

$\Delta S=S W_{E}-S W_{B}$

where $\Delta S$ is the amount change in soil water in the layer of 0 $100 \mathrm{~cm}, S W_{B}$ is the soil moisture measured at the beginning of growing period on May 1st in each year, $S W_{E}$ is the soil moisture measured at the end of the growing period on September 16th in each year.

The total annual surface runoff of each land cover type was calculated by the Eq. (2).

$Q=\frac{1}{3} \times \sum_{i=1}^{m} \sum_{k=1}^{3} Q_{i k}$

where $Q$ is the average surface runoff of the three plots for each land cover type in a year; $Q_{i k}$ is the surface runoff of each measurement in $k$ th plot; $\mathrm{m}$ is the total measurements made in a year.

The actual evapotranspiration (ET) for each plot was calculated as:

$E T=P-\Delta S-Q$

Ecosystem water stress was introduced by comparing actual evapotranspiration with potential evapotranspiration (PET), and actual evapotranspiration with annual rainfall $(P)$. In general, plants may face a water stress with a low ET/PET (Zhang et al., 2004 ) while a low water use efficiency exists with a low ET/P ratio. PET is calculated by summing up the daily pan evaporation.

\subsection{Regression data analysis}

Step-wise regression was performed to compare the effects of $S W_{B}, S W_{E}, Q$ and $P$ and $P E T$ on the ET/PET ratio. The ET/PET ratio was chosen as the dependent variable, and the $S W_{B}, S W_{E}, Q$ and $P$ and PET were independent variables. By this model, the contribution of $S W_{B}, S W_{E}, Q$ and $P$ and $P E T$ to the ET/PET ratio was identified. The $F$ tests were used to test hypotheses that individual variables were statistically significant at a level of $95 \%$. The partial coefficient for each independent variable indicates its importance in affecting the dependent variables.

\section{Results}

\subsection{Soil water variation}

Soil water storage varied greatly during the study period from 1986 to 1999 (Table 2). However, no significant differences were

Table 2

Soil water change $(\Delta S)$, surface runoff $(Q)$ and actual evapotranspiration (ET) for different land cover types from 1986 to 1999.

\begin{tabular}{|c|c|c|c|c|c|c|c|c|c|c|c|c|c|c|c|}
\hline & \multicolumn{3}{|l|}{ Cropland } & \multicolumn{3}{|c|}{ Alfalfa Grassland } & \multicolumn{3}{|c|}{ Native Grassland } & \multicolumn{3}{|c|}{ Sea Buckthorn } & \multicolumn{3}{|c|}{ Pine Woodland } \\
\hline & $\begin{array}{l}\Delta S \\
(0-100 \mathrm{~cm}) \\
(\mathrm{mm})\end{array}$ & $\begin{array}{l}Q \\
(\mathrm{~mm})\end{array}$ & $\begin{array}{l}E T \\
(\mathrm{~mm})\end{array}$ & $\begin{array}{l}\Delta S \\
(0-100 \mathrm{~cm}) \\
(\mathrm{mm})\end{array}$ & $\begin{array}{l}Q \\
(\mathrm{~mm})\end{array}$ & $\begin{array}{l}E T \\
(\mathrm{~mm})\end{array}$ & $\begin{array}{l}\Delta S \\
(0-100 \mathrm{~cm}) \\
(\mathrm{mm})\end{array}$ & $\begin{array}{l}Q \\
(\mathrm{~mm})\end{array}$ & $\begin{array}{l}E T \\
(\mathrm{~mm})\end{array}$ & $\begin{array}{l}\Delta S \\
(0-100 \mathrm{~cm}) \\
(\mathrm{mm})\end{array}$ & $\begin{array}{l}Q \\
(\mathrm{~mm})\end{array}$ & $\begin{array}{l}E T \\
(\mathrm{~mm})\end{array}$ & $\begin{array}{l}\Delta S \\
(0-100 \mathrm{~cm}) \\
(\mathrm{mm})\end{array}$ & $\begin{array}{l}Q \\
(\mathrm{~mm})\end{array}$ & $\begin{array}{l}E T \\
(\mathrm{~mm})\end{array}$ \\
\hline 1986 & -104.49 & 32.6 & 370.19 & -66.32 & 22 & 388.12 & -152.08 & 17.6 & 432.78 & -126.65 & 24.2 & 400.75 & -82.74 & 10.5 & 370.54 \\
\hline 1987 & 27.20 & 28.2 & 260.90 & 30.53 & 12.7 & 229.57 & 49.11 & 18.5 & 248.69 & 48.84 & 10.5 & 256.96 & 37.48 & 18.4 & 260.42 \\
\hline 1988 & -6.33 & 22 & 265.33 & -0.70 & 16.6 & 249.30 & -35.98 & 4.6 & 312.38 & -4.36 & 5.9 & 279.46 & 21.38 & 21.2 & 238.42 \\
\hline 1989 & 13.95 & 28.5 & 202.65 & -11.66 & 21.9 & 224.86 & -2.68 & 6 & 241.78 & -7.34 & 5.7 & 246.74 & -4.39 & 29.4 & 220.09 \\
\hline 1990 & -60.40 & 8.5 & 331.90 & -60.40 & 8.8 & 384.10 & -78.89 & 6.3 & 352.59 & -62.65 & 5.1 & 337.55 & -40.13 & 8.2 & 311.93 \\
\hline 1991 & -71.41 & 6 & 339.21 & -78.51 & 6.6 & 417.71 & -56.51 & 1.9 & 328.41 & -73.47 & 2.2 & 345.07 & -42.43 & 4.8 & 311.43 \\
\hline 1992 & 47.58 & 19.5 & 247.72 & 26.03 & 10.5 & 240.87 & 27.68 & 2.2 & 284.92 & 41.22 & 4.3 & 269.28 & 66.26 & 7.2 & 241.34 \\
\hline 1993 & -44.07 & 11.8 & 374.77 & -34.92 & 11.3 & 389.92 & -7.72 & 7.1 & 343.12 & -30.18 & 4.1 & 368.58 & -20.87 & 9.6 & 353.77 \\
\hline 1994 & 9.28 & 11.6 & 284.92 & 9.57 & 19 & 248.23 & 6.51 & 7.4 & 291.89 & 35.08 & 2.4 & 268.32 & 8.00 & 11.1 & 286.70 \\
\hline 1995 & 68.30 & 23.8 & 217.20 & 67.12 & 33.6 & 106.88 & 75.91 & 15 & 218.39 & 62.39 & 2.7 & 244.21 & 50.56 & 17 & 241.74 \\
\hline 1996 & -79.92 & 9.7 & 340.12 & -67.61 & 9.9 & 385.31 & -102.30 & 7.3 & 364.90 & -83.28 & 1.2 & 351.98 & -40.88 & 8.1 & 302.68 \\
\hline 1997 & -20.58 & 11.4 & 255.08 & -20.17 & 12 & 262.37 & -13.19 & 13.4 & 245.69 & -38.57 & 3.6 & 280.87 & 9.60 & 10.7 & 225.60 \\
\hline 1998 & -27.58 & 8 & 331.48 & -5.52 & 8.1 & 307.42 & -22.44 & 8.9 & 325.44 & -29.23 & 3.9 & 337.23 & -11.02 & 10.7 & 312.22 \\
\hline 1999 & 0.88 & 18.1 & 255.52 & 13.38 & 17.1 & 213.52 & 14.83 & 16.8 & 242.87 & 0.42 & 5.9 & 268.18 & 11.35 & 22.7 & 240.45 \\
\hline Sum & -247.59 & 240 & 4076.99 & -199.17 & 210.1 & 4048.17 & -297.75 & 133 & 4233.85 & -267.77 & 81.7 & 4255.17 & -37.82 & 189.6 & 3917.32 \\
\hline Average & -17.68 & 17.1 & 291.21 & -14.23 & 15.01 & 289.15 & -21.27 & 9.5 & 302.42 & -19.13 & 5.84 & 303.94 & -2.70 & 13.54 & 279.81 \\
\hline
\end{tabular}




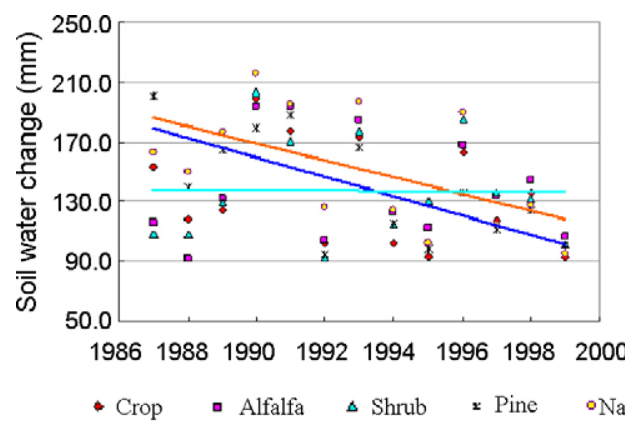

(a) May $1^{\text {st }}$, the beginning of growing season

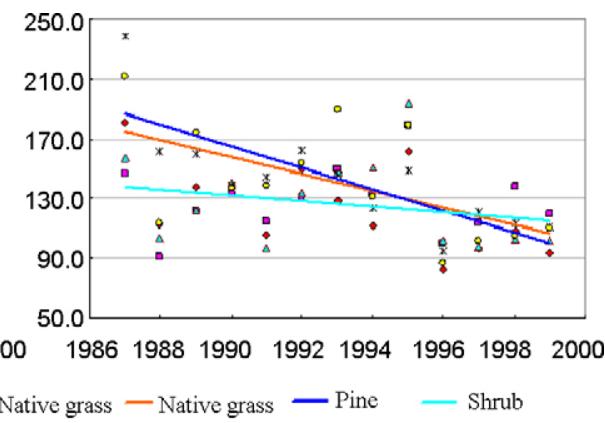

(b) Sep $16^{\text {th }}$, the end of growing season

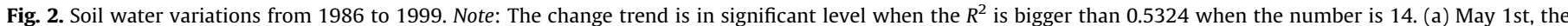
beginning of growing season. (b) Sep 16th, the end of growing season.

found among the five land cover types. Soil water surplus during growing seasons occurred in 1987, 1992, 1994, 1995, 1999, whereas soil water deficit occurred in 1986, 1988, 1990, 1991, 1993, 1996 and 1998. It was interesting that cropland had a soil water surplus in 1989 , and pine plantation in 1997, but not the other land cover types (Table 2). In general, a decrease trend was found for all land cover types both at the beginning and at the end of the growing seasons from 1986 to 1999 (Fig. 2). If land cover was examined, the slope of the decline trend of soil water storage for shrub lands was much lower than the other land cover types. However, pine woodland had a bigger decline slope compared with the native grasslands. This implies that pine plantation resulted in more soil water loss compared with shrub lands and native grasslands.

\subsection{Surface runoff}

Among the land cover types, pine plantations produced the largest surface runoff (Table 2). This was somewhat surprising since pines were considered as a major species for soil erosion control through reducing surface runoff in the study region. We attributed the large runoff to the soil compaction and lacking understory in the pine stands (Chen et al., 2007). In contrast, the low surface runoff of shrub lands and native grasslands had better ground coverage, lower soil bulk density, and higher infiltration rates.

\subsection{Characteristics of ET/PET ratio}

Rather low ET/PET ratio values were found for all land cover types, typical of semi-arid regions. Annual variability was observed (Table 3, Fig. 3), and the peak value appeared in 1990 and the lowest value

Table 3

Variation of ET/PET ratio of different land cover types from 1986 to 1999

\begin{tabular}{llllll}
\hline & Cropland & $\begin{array}{l}\text { Alfalfa } \\
\text { Grassland }\end{array}$ & $\begin{array}{l}\text { Sea } \\
\text { Buckthorn }\end{array}$ & $\begin{array}{l}\text { Pine } \\
\text { Woodland }\end{array}$ & $\begin{array}{l}\text { Native } \\
\text { Grassland }\end{array}$ \\
\hline 1986 & 0.277 & 0.260 & 0.296 & 0.277 & 0.315 \\
1987 & 0.172 & 0.179 & 0.170 & 0.172 & 0.166 \\
1988 & 0.200 & 0.200 & 0.209 & 0.185 & 0.228 \\
1989 & 0.211 & 0.231 & 0.239 & 0.222 & 0.236 \\
1990 & 0.313 & 0.312 & 0.316 & 0.300 & 0.326 \\
1991 & 0.256 & 0.259 & 0.259 & 0.239 & 0.249 \\
1992 & 0.215 & 0.235 & 0.229 & 0.211 & 0.239 \\
1993 & 0.280 & 0.275 & 0.276 & 0.267 & 0.260 \\
1994 & 0.206 & 0.201 & 0.196 & 0.207 & 0.210 \\
1995 & 0.145 & 0.140 & 0.160 & 0.159 & 0.146 \\
1996 & 0.249 & 0.242 & 0.256 & 0.227 & 0.264 \\
1997 & 0.148 & 0.148 & 0.162 & 0.132 & 0.143 \\
1998 & 0.253 & 0.240 & 0.257 & 0.242 & 0.250 \\
1999 & 0.227 & 0.220 & 0.235 & 0.218 & 0.220 \\
Average & 0.225 & 0.225 & 0.233 & 0.218 & 0.232 \\
\hline
\end{tabular}

in 1997. For example, the ET/PET ratio was 0.28 for the pine plantations in 1986 and a sharp decrease appeared in 1987 (0.17). Among all land covers, the ET/PET ratios ranked from high to low: shrub lands $>$ native grassland $>$ cropland $=$ alfalfa grassland $>$ pine plantation. This result suggested that planting pine would result in a heavier water stress compared to shrub land and native grassland.

A declining trend of ET/PET ratio was found in the study area from 1986 to 1999 (Fig. 3). Although the descending rate was small, it still showed that the water stress was becoming greater over time. Such situation may result in soil desiccation, and further plant death. If the landscape restoration types were compared, the decline slope of native grassland was the largest, followed by pine plantation and shrub lands.

\subsection{Characteristics of ET/P ratio}

The $E T / P$ ratios also fluctuated during the study period (Fig. 4). The ET/P ratio was bigger than 1.0 in 1986, 1990, 1991, 1993, 1996 and 1998 whereas it was below 1.0 in the other years (Table 4). Among all land cover types, the ratios ranked from high to low as shrub lands $>$ native grassland $>$ alfalfa grassland $>$ cropland $>$ pine plantation. Pine plantation, as a landscape restoration type, its $E T / P$ ratio was the lowest one among the five land cover types. This suggested that pine as an exotic species to the semi-arid Loess Plateau, did not use the rainfall resource adequately, perhaps due to greater water loss by overland flow. However, the slope of declining trend of $E T / P$ for the landscape restoration types was: native grassland $>$ pine woodland $>$ shrub lands.

Table 4

Variation of ET/P ratio of different land cover types from 1986 to 1999.

\begin{tabular}{llllll}
\hline & Cropland & $\begin{array}{l}\text { Alfalfa } \\
\text { Grassland }\end{array}$ & $\begin{array}{l}\text { Sea } \\
\text { Buckthorn }\end{array}$ & $\begin{array}{l}\text { Pine } \\
\text { Woodland }\end{array}$ & $\begin{array}{l}\text { Wild } \\
\text { Grassland }\end{array}$ \\
\hline 1986 & 1.189 & 1.116 & 1.269 & 1.190 & 1.353 \\
1987 & 0.850 & 0.883 & 0.839 & 0.849 & 0.817 \\
1988 & 0.956 & 0.955 & 0.996 & 0.880 & 1.088 \\
1989 & 0.887 & 0.973 & 1.004 & 0.934 & 0.991 \\
1990 & 1.116 & 1.115 & 1.128 & 1.071 & 1.162 \\
1991 & 1.176 & 1.194 & 1.192 & 1.101 & 1.147 \\
1992 & 0.831 & 0.908 & 0.885 & 0.815 & 0.925 \\
1993 & 1.082 & 1.060 & 1.067 & 1.029 & 1.002 \\
1994 & 0.942 & 0.921 & 0.896 & 0.947 & 0.961 \\
1995 & 0.737 & 0.712 & 0.814 & 0.807 & 0.740 \\
1996 & 1.202 & 1.166 & 1.237 & 1.094 & 1.274 \\
1997 & 1.035 & 1.031 & 1.132 & 0.923 & 0.999 \\
1998 & 1.047 & 0.994 & 1.061 & 1.001 & 1.033 \\
1999 & 0.953 & 0.924 & 0.984 & 0.915 & 0.921 \\
Average & 1.000 & 0.997 & 1.036 & 0.968 & 1.030 \\
\hline
\end{tabular}


$\begin{array}{llllllllllllll}1986 & 1987 & 1988 & 1989 & 1990 & 1991 & 1992 & 1993 & 1994 & 1995 & 1996 & 1997 & 1998 & 1999\end{array}$

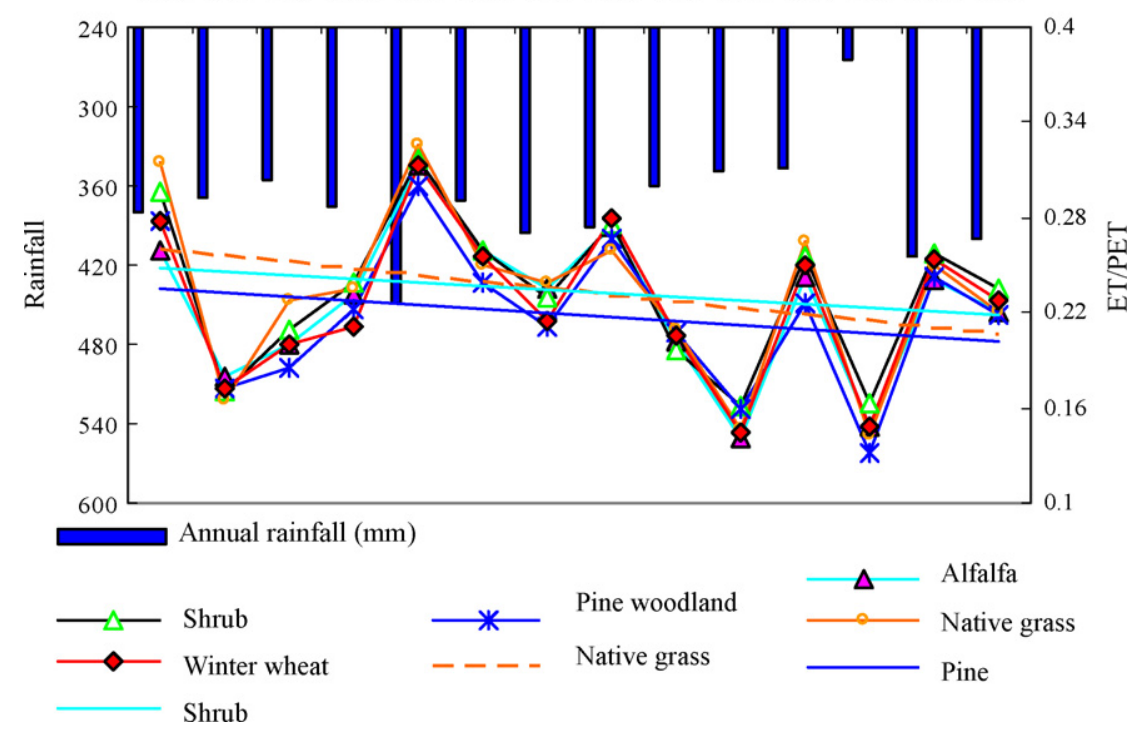

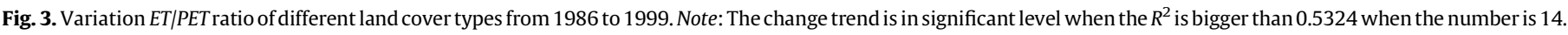

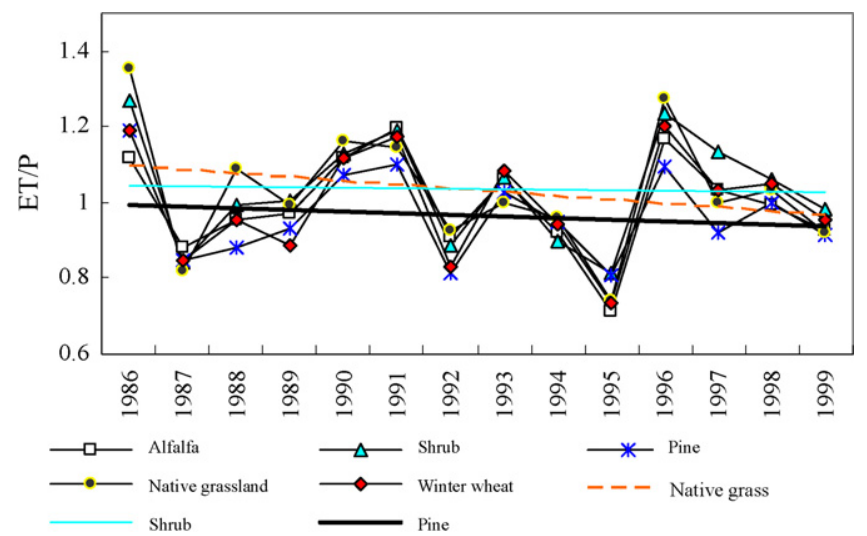

Fig. 4. The ratio of ET/P of different land cover types from 1986 to 1999.

\subsection{Relationship between $S W, Q, P, P E T$ and ET/PET ratio}

The regression analysis suggested that $S W_{B}$ were the most significant variable to affect the ET/PET ratio (Table 5). If the $S W_{B}$ was not considered, the effect of $S W_{E}, Q, P$, and PET on the ET/PET ratio differed for land cover types (Table 6 ). Except for the alfalfa grassland, rainfall became the determinant factor to affect the ET/ $P E T$ ratio, and $S W_{E}$, surface runoff and potential evapotranspiration were excluded. However, rainfall, surface runoff and potential evapotranspiration had effects on the ET/PET ratio for the alfalfa grasslands in the order: $P>Q>P E T$. In general, rainfall had a positive effect on the ET/PET ratio, whereas both surface runoff and potential evapotranspiration had a negative effect on it.

\section{Discussion}

\subsection{Effect of land cover on soil water variation}

Vegetation restoration may affect soil water dynamic and balance by increasing evapotranspiration and reducing runoff (Sun et al., 2006; Oudin et al., 2008). However, it was not the case in our study (Table 2). After vegetation restoration such as the pine plantation, evapotranspiration decreased and surface runoff increased in the time period. This was mainly due to the soil compaction caused by pine plantation, resulting in further low infiltration and high surface runoff (Hu et al., 2007). These results were also confirmed by other studies. For example, Kosmas et al. (1997) and Vacca et al. (2000) described the favorable conditions for runoff and erosion under Eucalyptus forest as related to prevailing bare soil conditions due to decreased understory

Table 5

Summary of the step-wise regression model I.

\begin{tabular}{|c|c|c|c|c|c|c|c|}
\hline \multirow{2}{*}{$\begin{array}{l}\text { Dependent } \\
\text { variable }(E T)\end{array}$} & \multirow{2}{*}{$\begin{array}{l}\text { Independent } \\
\text { variables }\end{array}$} & \multirow{2}{*}{$\begin{array}{l}\text { Unstandardized } \\
\text { coefficient } B\end{array}$} & \multirow{2}{*}{$\begin{array}{l}\text { Standardized } \\
\text { coefficient Beta }\end{array}$} & \multirow[t]{2}{*}{$t$} & \multirow[t]{2}{*}{ sig } & \multicolumn{2}{|c|}{ Model summary } \\
\hline & & & & & & $R^{2}$ & Adjusted $R^{2}$ \\
\hline \multirow[t]{2}{*}{ Cropland } & Constant & $5.477 \mathrm{E}-03$ & & 0.234 & 0.819 & 0.885 & 0.885 \\
\hline & $S W_{B}$ & 0.772 & 0.941 & 9.618 & 0.000 & & \\
\hline \multirow[t]{2}{*}{ Alfalfa Grassland } & Constant & $9.244 \mathrm{E}-03$ & & 0.381 & 0.710 & 0.871 & 0.860 \\
\hline & $S W_{B}$ & 0.754 & 0.933 & 8.991 & 0.000 & & \\
\hline \multirow[t]{2}{*}{ Native Grassland } & Constant & $9.418 \mathrm{E}-03$ & & 0.037 & 0.971 & 0.877 & 0.867 \\
\hline & $S W_{B}$ & 0.793 & 0.937 & 9.266 & 0.000 & & \\
\hline \multirow[t]{2}{*}{ Sea Buckthorn } & Constant & $-4.875 \mathrm{E}-03$ & & -0.181 & 0.859 & 0.872 & 0.861 \\
\hline & $S W_{B}$ & 0.814 & 0.934 & 9.035 & 0.000 & & \\
\hline \multirow[t]{2}{*}{ Pine Woodland } & Constant & $-5.735 \mathrm{E}-03$ & & -0.221 & 0.829 & 0.866 & 0.854 \\
\hline & $S W_{B}$ & 0.809 & 0.930 & 8.794 & 0.000 & & \\
\hline
\end{tabular}

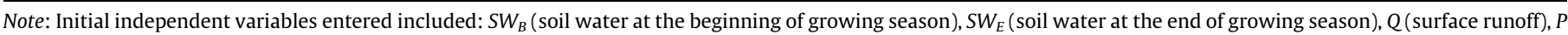
(annual rainfall) and PET (potential evapotranspiration), only $S W_{B}$ was identified as the significant variable to affect $E T / P E T$, and the other variables were excluded. 
Table 6

Summary of the step-wise regression model II.

\begin{tabular}{|c|c|c|c|c|c|c|c|}
\hline \multirow{2}{*}{$\begin{array}{l}\text { Dependent } \\
\text { variable }(A E T)\end{array}$} & \multirow{2}{*}{$\begin{array}{l}\text { Independent } \\
\text { variables }\end{array}$} & \multirow{2}{*}{$\begin{array}{l}\text { Unstandardized } \\
\text { coefficient } B\end{array}$} & \multirow{2}{*}{$\begin{array}{l}\text { Standardized } \\
\text { coefficient Beta }\end{array}$} & \multirow[t]{2}{*}{$t$} & \multirow[t]{2}{*}{$\operatorname{sig}$} & \multicolumn{2}{|c|}{ Model summary } \\
\hline & & & & & & $R^{2}$ & Adjusted $R^{2}$ \\
\hline Cropland & $\begin{array}{l}\text { Constant } \\
P\end{array}$ & $\begin{array}{r}-8.239 \mathrm{E}-2 \\
8.253 \mathrm{E}-04\end{array}$ & 0.700 & $\begin{array}{r}-0.903 \\
3.395\end{array}$ & $\begin{array}{l}0.385 \\
0.005\end{array}$ & 0.490 & 0.447 \\
\hline Alfalfa Grassland & $\begin{array}{l}\text { Constant } \\
P \\
Q \\
P E T\end{array}$ & $\begin{array}{l}0.414 \\
4.581 \mathrm{E}-04 \\
-2.453 \mathrm{E}-03 \\
-1.941 \mathrm{E}-04\end{array}$ & $\begin{array}{r}0.409 \\
-0.385 \\
-0.410\end{array}$ & $\begin{array}{r}2.050 \\
2.216 \\
-2.622 \\
-2.253\end{array}$ & $\begin{array}{l}0.067 \\
0.051 \\
0.026 \\
0.048\end{array}$ & 0.794 & 0.732 \\
\hline Native Grassland & $\begin{array}{l}\text { Constant } \\
P\end{array}$ & $\begin{array}{l}-0.112 \\
9.251 \mathrm{E}-04\end{array}$ & 0.700 & $\begin{array}{r}-1.094 \\
3.400\end{array}$ & $\begin{array}{l}0.295 \\
0.005\end{array}$ & 0.491 & 0.448 \\
\hline Sea Buckthorn & $\begin{array}{l}\text { Constant } \\
P\end{array}$ & $\begin{array}{r}-7.736 \mathrm{E}-02 \\
8.348 \mathrm{E}-04\end{array}$ & 0.693 & $\begin{array}{r}-0.821 \\
3.327\end{array}$ & $\begin{array}{l}0.428 \\
0.006\end{array}$ & 0.480 & 0.436 \\
\hline Pine woodland & $\begin{array}{l}\text { Constant } \\
P\end{array}$ & $\begin{array}{l}-0.111 \\
8.820 \mathrm{E}-04\end{array}$ & 0.773 & $\begin{array}{r}-1.410 \\
4.217\end{array}$ & $\begin{array}{l}0.184 \\
0.001\end{array}$ & 0.597 & 0.563 \\
\hline
\end{tabular}

Note: Initial independent variables entered included: $S W_{E}$ (soil water at the end of growing season), $Q$ (runoff), $P$ (rainfall) and $P E T$ (potential evapotranspiration).

vegetation. A positive correlation between soil bulk density and the surface runoff was indicated by Gutierrez and Hernandez (1996) and Calvo-Casses et al. (2003). High soil bulk density usually corresponds to a lack of soil structure and as such to lower infiltration rates and higher runoff depths (Descheemaeker et al., 2006). However, the better soil water conservation of shrub lands and native grassland than pine woodland is largely due to the lower soil bulk density and better understory (Gong et al., 2006; Wang et al., 2003, 2005).

In general, land cover types produce different impacts on soil water variation. However, our results did not show a significant difference among the land cover types (Table 2). Other studies also showed different results in the other areas of the Loess Plateau. For example, Liu and Huang (2002) found that the available soil water in the depth of $0-10 \mathrm{~m}$ decreased with apple trees growing up. Wang et al. (2002) found that lands with native species had normally higher soil moisture than those with exotic species, and landscape restoration may result in soil desiccation if exotic species were employed in the Loess Plateau. The difference between our studies and the above-mentioned studies is because of the difference in rainfall. In our studies, the annual rainfall was almost all used by plants for evapotranspiration and little for soil water recharge during the growing season. However, other studies that focused on the Loess Plateau with more rainfall may show the differences in ET among different land uses.

Apart from shrub lands, soil water was not appropriately replenished for the other land cover types over a long time period (Fig. 2). Soil water for pine woodlands and native grasslands had a clear declining trend at both the beginning and the end of growing seasons from 1986 to 1999. Soil water in shrub lands at the beginning of growing season was nearly balanced. Normally, arborvitae has a strong evapotranspiration and soil water decreases clearly under the deep soil in the dry season (Yang and Rong, 2007). In the Loess Plateau, planting pine was not always considered a suitable way. A study by Wei et al. (2007) indicated that soil water was at a better state at the early stage of tree plantation but not in the late stage. Some studies also showed that soil desiccation was developed under a 28-year-old tree plantation, and however better soil moisture was often observed under the natural forest or grassland (Zheng et al., 2008). In our study, all ecosystems had a poor soil water condition during the growing seasons.

\subsection{Effect of land cover on ET/PET and ET/P}

Low ET/PET and ET/P ratios were found for all land cover types in the study area. This is because of the deficient rainfall and high potential evapotranspiration. It implies that all land cover types cannot get sufficient water in the growing seasons for evapotranspiration and growth. The declining trend observed on the ET/ PET and ET/P ratios denoted that water stress faced by vegetation was becoming severe as plants growing up. This was also confirmed by Hou et al. (1999) and Liu and Huang (2002) that artificial vegetation would degrade after some years due to water depletion. The high potential evapotranspiration exceeds the annual rainfall in the semi-arid Loess Plateau, and water loss by high runoff, is extremely unfavorable for plant growth. If the runoff-to-precipitation ratio is fairly high, the actual evapotranspiration are then likely to be low (Ordin et al., 2008). Some studies demonstrated that plant evapotranspiration in the loess hilly areas was becoming less with soil water decreased and water use efficiency declined (Yang et al., 2004). Thus, artificial tree plantation may resulted in "small aged tree" after some long time (Hou et al., 1999). This phenomenon is not the initial expect of landscape restoration, and may hit the public motivation on landscape restoration.

If land cover types were compared, a lower ET/PET ratio was found for the pine plantations. This is attributed to soil compaction. It differs from the other studies conducted in the humid regions that soil bulk density reduced significantly after vegetation restoration while soil porosity, water-holding capacity, aggregate stability, and saturated hydraulic conductivity increased (Li and Shao, 2006). However, in the semi-arid Loess Plateau, soil bulk density under pine stands became bigger with tree growing up (Gong et al., 2006). Consequently, little rainfall infiltrated into the soil to supply the deep soil water, and hereby much more runoff produced. Some studies on reforestation may increase surface runoff after forest reestablishments (Vanclay, 2009; Zheng et al., 2008). Zhou et al. (2002) also attributed the higher runoff coefficient under eucalyptus trees to a lower litter cover and poor understory compared with the mixed forests.

\subsection{Effect of $S W, P, Q$ and PET on ET/PET, ET/P}

Regression analysis showed that soil water at the beginning of growing seasons $\left(S W_{B}\right)$ (Table 5 ) played a more significant role in affecting $E T / P E T$ ratio than rainfall. Soil water at the end of growing seasons $\left(S W_{E}\right)$, surface runoff $(Q)$, potential evapotranspiration were excluded from the model except regarding to the alfalfa grassland. This is contrary to the general wisdom (Zhang et al., 2001) that rainfall was considered the most dominant factor in determining evapotranspiration, followed by potential evapotranspiration. The long-term evapotranspiration is determined by the 
local interaction of rainfall and potential evapotranspiration, regulated by soil water storage. However, our study suggested that soil water at the beginning of growing seasons was the most significant factor to affect the ET/PET ratio, then rainfall. In fact, the low ET/PET ratio implies that rainfall is below the water demand of plant growth, resulting in consuming large soil water. Soil water at the beginning of the growing seasons may determine the water availability for plant growth, and further the ET/PET ratio. As for alfalfa grassland, the complex effects of $S W_{B}, P, Q$ and PET on the ET/ $P E T$ ratio may be resulted from the frequent disturbance of human harvests.

The low ET/P ratio indicates low rainfall use efficiency. Normally, mean annual evapotranspiration approaches precipitation in the extreme arid regions, and conversely, it approaches potential evapotranspiration where precipitation is significantly higher than potential evapotranspiration (Zhang et al., 2004). As a sole water source for plant growth, rainfall in the semi-arid Loess Plateau is key factor for successful landscape restoration (Li, 2001; Shangguan and Zheng, 2006). If the rainfall seasonality and the potential evapotranspiration are out of phase, landscape restoration will be greatly restricted. However, the rainfall resource was poorly used because of tree selection in the semi-arid Loess Plateau, and few studies addressed these issues by now (Wu and Yang, 1998).

In this study, the regular cycle on the ET/PET and ET/P ratios (Tables 3 and 4, Figs. 3 and 4) in the time period indicated a natural ecohydrological cycle between rainfall, soil water variation and evapotranspiration. Some studies also indicated that temporal variability of precipitation resulted in large variability of evapotranspiration (Yokoo et al., 2008). This pattern suggests that a year in heavy water stress for plant growth may follow a rather wet year. Thus, much attention should be paid to the plant water stress, particularly after a rainfall-rich year, and measures are to be adopted on water conservation.

Although a decreasing trend on rainfall and increasing trend on potential evapotranspiration was found, both of them are not significant (Fig. 5). However, the declining trend of ET/PET and $E T / P$ ratios indicated that plant growth in the semi-arid Loess Plateau was facing an increasing water stress. The regression results suggested that soil water at the beginning of growing seasons was the determinant factor to affect the ET/PET ratio, and the overload consumption on soil water and insufficient water replenishment may result in soil water desiccation and lead to heavy water stress for the plant growth. However, the greater slope on soil water decrease of native grassland should be further investigated.

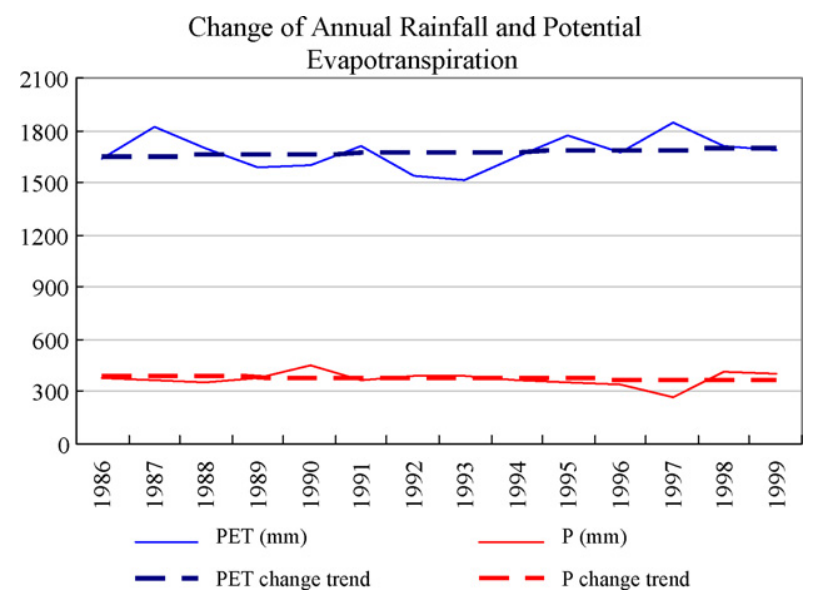

Fig. 5. Annual rainfall and potential evapotranspiration from 1986 to 1999.

\section{Conclusions}

Soil water is normally replenished from rainfall during rainy seasons. However, our study showed that such replenishment was not sufficient, and soil water deficits frequently occurred from 1986 to 1999. This was due to low rainfall, strong plant evapotranspiration and overland flow, especially for the pine plantation. Such deficits severely restricted plant transpiration and growth. For landscape restoration, pine plantation produced the largest surface runoff when compared with planting shrubs and native grasses. Although pine plantations may be good for soil conservation, it compounded soil compaction and desiccation, thus leading to landscape degradation. Therefore, pine plantation should not be the first choice for landscape restoration in such a semi-arid loess hilly area; instead, shrub plantation should be considered for the restoration purpose.

An extremely low ET/PET ratio in the growing seasons was found for all land cover types in our study; the ET/PET and ET/P ratios tended to decline with plants growing up. This suggests that plants were not supplied with sufficient water needed for evapotranspiration and growth and all land cover types experienced water stresses.

The soil water at the beginning of the growing seasons and the annual rainfall largely determined the ET/PET ratio, indicating that the water availability was critical for plant growth. The ET/PET ratio variation revealed from our long-time field observations may be related to ecohydrological cycle among rainfall, soil water variation, plant evapotranspiration. In addition, the temporal ET/ $P$ variation suggests that plant growth was not steady, which was unfavorable for sustainable water use and landscape restoration. We believe that both plant species and water conservation techniques should be considered when implementing landscape restoration in the semi-arid regions. We highly recommend shrub plantation and native grassland for landscape restoration.

\section{Acknowledgements}

Financial support for this research came from the National Natural Science Foundation of China Projects (40621061 and 40925003) and the Chinese Academy of Sciences (KZCX2-YW-421).

\section{References}

Calvo-Cases, A., Boix-Fayos, C., Imeson, A.C., 2003. Runoff generation, sediment movements and soil water behavior on calcareous (limestone) slopes of some Mediterranean environments in southeast Spain. Geomorphology 50, 269-291.

Chen, H.S., Shao, M.A., Li, Y.Y., 2008. The characteristics of soil water cycle and water balance on steep grassland under natural and simulated rainfall conditions in the Loess Plateau of China. Journal of Hydrology 360, 242-251.

Chen, L.D., Huang, Z.L., Gong, J., Fu, B.J., Huang, Y.L., 2007. The effect of land cover/ vegetation on soil water dynamic in the hilly area of the loess plateau, China. Catena 70, 200-208.

Descheemaeker, K., Nyssen, J., Poesen, J., Raes, D., Haile, M., Muys, B., Deckers, S., 2006. Runoff on slopes with restoring vegetation: a case study from the Tigray highlands, Ethiopia. Journal of Hydrology 331, 219-241.

Fu, B.J., Zhao, W.W., Chen, L.D., Zhang, Q.J., Lu, Y.H., Gulinck, H., Poesen, J., 2005. Assessment of soil erosion at large watershed scale using RUSLE and GIS: a case study in the Loess Plateau of China. Land Degradation and Development 16, 7385.

Gong, J., Chen, L.D., Fu, B.J., Huang, Y.L., Huang, Z.L., Peng, H.J., 2006. Effect of land use on soil nutrients in the loess hilly area of the Loess Plateau, China. Land Degradation and Development 17, 453-465.

Gutierrez, J., Hernandez, I.I., 1996. Runoff and inter-rill erosion as affected by grass cover in a semi-arid rangeland of northern Mexico. Journal of Arid Environments 34, 287-295.

Hou, Q.C., Han, R.L., Han, S.F., 1999. The preliminary research on the problems of soil drying in artificial forest and grass land in the Loess Plateau. Soil and Water Conservation in China 5, 11-14 (In Chinese with English abstract)

Hu, J.B., Yang, G.H., He, G.Q., Zhang, X.P., Liu, Z.C., Huai, Z.A., Li, H.P., 2007. Ecological effects Soil Moisture in different vegetation recovery modes. China Soil and Water Conservation 10, 29-31 (In Chinese with English abstract).

Huang, M., Yang, X., Li, Y., 2001. Effect on regional water cycle of apple base in Weibei Upland of the Loess Plateau. Journal of Geographical Sciences 3 (1), 23 28 (In Chinese with English abstract). 
Huang, M.B., Gallichand, J., 2006. Use of the SHAW model to assess soil water recovery after apple trees in the gully region of the Loess Plateau, China. Agricultural Water Management 85 (1-2), 67-76.

Huang, M.B., Yang, X.M., Li, Y.S., 2003. Hydro-ecological effect of the soil dry layer as affected by biota use in the Loess Plateau. Chinese Journal of Eco-Agriculture 11 (3), 113-116 (In Chinese with English abstract).

Kosmas, D., Danalatos, N., Cammeraat, L.H., Chabart, M., 1997. The effect of land use on runoff and soil erosion rates under Mediterranean conditions. Catena 29, 4559.

Li, Y.S., 2001. Effects of forest on water circle on the Loess Plateau. Journal of Natural Resources 16 (5), 427-432 (In Chinese with English abstract).

Li, Y.Y., Shao, M.A., 2006. Change of soil physical properties under long-term natural vegetation restoration in the Loess Plateau of China. Journal of Arid Environments 64, 77-96.

Liu, X., Huang, M., 2002. Effect of apple tree growth on soil water storage in the Weibei Upland of China. Journal of Horticulture Sciences 19 (1), 75-78 (In Chinese with English abstract).

Mu, X.M., Xu, X.X., Wang, W.L., Wen, Z.M., Du, F., 2003. Impact of artificial forest on soil moisture of the deep soil layer on Loess Plateau. Acta Pedologica Sinica 40 (2), 210-217 (In Chinese with English abstract).

Nosetto, M.D., Jobbagy, E.G., Toth, T., Di Bella, C.M., 2007. The effects of tree establishment on water and salt dynamics in naturally salt-affected grasslands. Oecologia 152, 695-705.

Oudin, L., Andréassian, V., Lerat, J., Michel, C., 2008. Has land cover a significant impact on mean annual stream flow? An international assessment using 1508 catchments. Journal of Hydrology 357, 303-316.

Porporato, A., D'Odorico, P., Laio, F., Ridolfi, L., Rodriguez-Iturbe, I., 2002. Ecohydrology of water-controlled ecosystems. Advances in Water Resources 25, 1335-1348.

Ran, W., Xie, Y.S., Hao, M.D., 2008. Study on change of soil water in orchards of different planting-life in gully region of Loess plateau. Acta Agriculture Borealioccidentalis Sinica 17 (4), 229-233.

Shangguan, Z.P., Zheng, S.X., 2006. Ecological properties of soil water and effects on forest vegetation in the Loess Plateau. International Journal of Sustainable Development and World Ecology 13, 307-314.

Sun, G., Zhou, G.Y., Zhang, A.Q., Wei, X.H., McNulty, S.G., Vose, J.M., 2006. Potential water yield reduction due to forestation across China. Journal of Hydrology 328, 548-558.

Vanclay, J.K., 2009. Managing water use from forest plantations. Forest Ecology and Management 257, 385-389.

Wang, G.L., Liu, G.B., Chang, X., Xu, M.X., 2002. A study on the effect of soil water on vegetation rehabilitation in watershed of loess hilly area. Journal of Natural Resource 17, 339-344 (In Chinese with English abstract).

Wang, G.L., Liu, G.B., Zhou, S.L., 2003. The effect of vegetation restoration on soil stable infiltration rates in small watershed of loess gully region. Journal of Natural Resource 18, 529-535 (In Chinese with English abstract).

Wang, H.S., 2007. Discussion on feedback effect of soil desiccation by vegetation and related issues. Progress in Geography 26 (6), 33-39 (In Chinese with English Abstract).
Wang, X.L., Chen, M.C., Li, F.M., Li, Y.J., 2007. Water restoration of dry soil layers in the Loess Plateau and crop yield response. Research of Soil and Water Conservation 14 (3), 1-4 (In Chinese with English abstract).

Wang, Z.Q., Liu, B.Y., Wang, X.L., 2005. Effects of natural shrub of Caragana Opulens on soil moisture in a semiarid area on the Loess. Geographical Research 24 (1), 113-120 (In Chinese with English abstract).

Wei, J., Zhou, J., Tian, J.L., He, X.B., Tang, K.L., 2006. Decoupling soil erosion and human activities on the Chinese Loess Plateau in the 20th century. Catena 68, 10-15.

Wei, T.X., Zhu, J.Z., Zhang, J.J., Bi, H.X., Zhu, Q.K., 2007. Protective forest system at small watershed in the gullied-hilly loess area based on water balance on the Loess Plateau. Research of Soil and Water Conservation 14, 179-183 (In Chinese with English abstract).

Wu, Q.X., Yang, W.Z. (Eds.), 1998. Vegetation Construction and Sustainable Development on the Loess Plateau. Science Press, Beijing, (In Chinese with English abstract), pp. 1-15.

Xu, Y., Tang, Q. Zhang, T.S., Yang, Q.K., 2009. Influence of ecological defarming scenarios on agriculture in An'sai County, Loess Plateau, China. Mountain Research and Development 29, 36-45.

Yang, G., Rong, L.Y., 2007. Effects of artificial vegetation types on soil moisture, carbon and nitrogen in the hill and gully area of the Loess Plateau. Bulletin of Soil and Water Conservation 27 (6), 30-33 (In Chinese with English abstract).

Yang, J.W., Liang, Z.S., Han, R.L., Wang, P.Z., 2004. Growth and water consumption characteristics of Chinese pine under soil drought stress. Journal of Northwest Science -Tech University of Agriculture and Forestry (Natural Sciences A) 32 (4), 88-92 (In Chinese with English abstract).

Yang, W.Z., Tian, J.L., 2004. Essential exploration of soil dissection in Loess Plateau. Acta Pedologica Sinica 41 (1), 1-6 (In Chinese with English abstract).

Yokoo, Y., Sivapalan, M., Oki, T., 2008. Investigating the roles of climate seasonality and landscape characteristics on mean annual and monthly water balances. Journal of Hydrology 357, 255-269.

Yuan, H.Y., Xu, X.N., 2004. Soil water dynamics of plantations in sub-arid gully and hilly regions of the Loess Plateau. Journal of Northwest Forestry University 19 (2), 5-8 (In Chinese with English abstract).

Zhang, L., Dawes, W.R., Walker, G.R., 2001. Response of mean annual evapotranspiration to vegetation changes at catchment scale. Water Resources Research 37, 701-708.

Zhang, L., Hickel, K., Dawes, W.R., Chiew, F.H.S., Western, A.W., Briggs, P.R., 2004. A rational function approach for estimating mean annual evapotranspiration. Water Resource Research 40, W02502, doi:10.1029/2003WR002710.

Zhang, X.P., Yang, G.H., Hu, J.B., Wang, D.X., 2008. Effect of different vegetation recovery modes on soil moisture ecoeffects in hilly and gully region of the Loess Plateau. Journal of Natural Resources 23, 635-642 (In Chinese with English abstract).

Zheng, H., Chan, F.L., Ouyang, Z.Y., Tu, N.M., Xu, W.H., Wang, X.K., Miao, H., Li, X.Q. Tian, Y.X., 2008. Impacts of reforestation approaches on runoff control in the hilly red soil region of Southern China. Journal of Hydrology 356, 174-184.

Zhou, G.Y., Morris, J.D., Yan, J.H., Yu, Z.Y., Peng, S.L., 2002. Hydrological impacts of reforestation with eucalypts and indigenous species: a case study in southern China. Forest Ecology and Management 167, 209-222. 